over to another a paper noticing all pre-requisites concerning the affair; and by names of the parents of the intended couple asks a man to pray and divine; and if the presage tells that the union is a lucky one, clothes and ornaments are made for the deceased pair. Now the match-maker goes to the buryingground of the bridegroom and, offering wire and fruits, requests the pair to marry. There two seats are prepared on adjoining positions, either of which having behind it a small banner more than a foot long. Before the ceremony is consecrated by libation, the two banners remain hanging perpendicularly and still; but when the libation is sprinkled and the deceased couple are requested to marry, the banners commence to gradually approach till they touch one another, which shows that they are both glad of the wedlock. However, when one of them dislikes another, it would happen that the banner representing the unwilling party does not move to approach the other banner. In case the couple should die too young to understand the matter a dead man is appointed as a tutor to the male defunct, and some effigies are made to serve as the instructress and maids to the female defunct. ${ }^{1}$ The dead tutor thus nominated is informed of his appointment by a paper offered to him, on which are inscribed his name and age. After the consummation of the marriage the new consorts appear in dreams to their respective parents-in-law. Should this custom be discarded, the unhappy defuncts might do mischief to their negligent relatives. . . . On every occasion of these nuptials both families give some presents to the match-maker ('Kwei-mei'), whose sole business is annually to inspect the newly-deceased couples around his village, and to arrange their weddings to earn his livelihood."

This passage is very interesting, for, besides giving us a faith ful account of the particulars, which nowadays we fail to find elsewhere, it bears testimony to the Tartar, and not Chinese, origin of this practice. The author, Kang Yu.chi, describes himself to have visited his old home in Northern China shortly after its subjugation by the Kin Tartars in II26 A.D.; so there is no doubt that among many institutional novelties then introduced to China by the northern invaders, Marriage of the Dead was so striking that the author did not hesitate to describe it for the first time.

According to a Persian writer, after whom Pétis de Lacroix writes, this custom was adopted by Jenghiz Kân as a means to preserve amity amongst his subjects, it forming the subject of Article XIX. of his Yasa promulgated in 1205 A.D. The same writer adds :- "This custom is still in use amongst the Tartar at this day, but superstition has added more circumstances to it : they throw the contract of marriage into the fire after having drawn some figures on it to represent the persons pretended to be so marry'd, and some forms of beasts; and are persuaded that all this is carried by the smoke to their children, who thereupon marry in the other world" (Pétis de Lacroix, "I History of Genghizcan the Great," trans. P. Aubin, London, I 722, p. 86). As the Chinese author does not speak of the burning of papers in this connection, whereas the Persian writer speaks definitely of its having been added later, it seems that the marriage of the dead had been originally a Tartar custom, with which the well-known Chinese paper-burning was amalgamated subsequently between the reigns of Genghiz and his grandson Kublai--under the latter Marco witnessed the customs already mingled, still, perhaps, mainly prevailing amongst the Tartar descerdants. Kumagusu Minakata.

\section{The Heating of Anodes in X-Ray Tubes.}

IN reply to Mr. Walter Chamberlain's inquiry (p, 198), it must be borne in mind that spark length is not per se a criterion of the energy delivered to a vacuum tube. The length of spark is more or less proportionate to the maximum E.M.F. of the discharge, while the energy of a discharge depends upon the nature of the curves of both E.M.F. and current, and may bear but a small relation to the maximum E.M.F. Large coils which have secondary wire of considerable section and comparatively large electrostatic capacity, give a much greater electric quantity and, consequently, much more energy for each discharge, even when worked so as to give only short sfarks, than do smaller coils the secondary wire of which is of smaller section and capacity.

Röntgen-ray tubes should be excited during exhaustion with a

1 The last clause in original text is doubtful in reading. Perhaps it will be more correct to render it : "And the family of the intended bride provides her with various sorts of utensils and apparel needful to her nurse and mail-servants in the other world." coil of the same dimensions as the one that they are ultimately destined to be worked with. This is a point which does not seem to receive sufficient attention from commercial tube manufacturers.

66 Victoria Street, London, S.W., January I.

\section{Sesamoid Bones.}

JUDGING from a small collection of $\mathrm{X}$-ray photographs made during the year, the female hand seems better provided with sesamoid bones than the male.

In my prints, in the female hand a sesamoid is most often found in the metacarpo-phalangeal joint of the little finger, less frequently in the index : in one case there are two in the interphalangeal joint of the thumb; in this hand, including the two always found in the metacarpo-phalangeal joint of the thumb, there are no less than six sesamoids. In male hands the bones seem to be more evenly divided between the index and fifth fingers. In most cases the sesamoids are larger in the female hand.

December 26,1896

F. J. REIn.

\section{Discharge of Electricity by Phosphorus.}

THE discharging power for electricity of slowly oxidising phosphorus appears to have been known for much longer than Messrs. Elster and Geitel (see p. I 55) seem to be aware of.

In the I 855 edition of the "Encyclopædia Britannica," vol. viii. p. 622, an apparatus is described for collecting atmospheric electricity, first used by Matteucci, in which a piece of phosphorns projecting from a glass tube is connected to an electrometer by a long wire, and exposed to the air whose electrical state is to be investigated. It is said to have been found very useful for this purpose.

Rochdale, December 26, I896.

\section{Shooting-stars observed on January 2.}

THis morning, between six and seven o'clock, there has been a very unusual number of shooting-stars. The radiant point was somewhere near Corona. I saw, on the whole, two or three dozen. The brightest was not much inferior to Jupiter. Sheffield, January 2.

H. C. SORBr.

\section{THE GEODETTC SURVEY OF SOUTH $A F R I C A{ }^{1}$}

THE Report on the Geodetic Survey of South Africa, presented to both Houses of the Cape Parliament, and printed in Blue-book form, is interesting and important. It is a record of geodetic work well planned and ably carried out, and it has a permanent value, not only from a scientific point of view, but as an accurate basis upon which all future surveys of the country may be confidently founded.

Soon after his appointment as H.M.'s Astronomer at the Cape in 1879 , Dr. Gill recommended that a geodetic survey should be commenced, and formulated a scheme "for a gridiron system of chains of principal triangulation extending over the Cape Colony, the Orange Free State, Natal, and the Transvaal." His recommendations were cordially supported by Sir Bartle Frere and Sir George Colley, then respectively Governors of the Cape Colony and Natal ; but it was not until June 1883 that the work was fairly commenced, by the measurement of a baseline in Natal. On the completion of this operation, severe pressure was applied by the Government of Natal to accelerate the work at the expense of accuracy; and on two subsequent occasions the question of suspending the survey was seriously considered. It was no easy task to convince Governors and Ministers that true economy lay in "basing all future surveys upon a principal triangulation of such accuracy, that its results might be

1 " Report on the Geodetic Survey of South Africa." Executed by Litut. Colonel Morris, R.E., C.M.G., under the direction of David Gill, H.M. Astronomer at the Cape. Parliamentary Paper. Pp. xii +291 . (Cine Town: Richards, 1896 .)

No. 1439 , VOL. 55$]$ 
considered definitive for all future time"; but Dr. Gill succeeded. By a happy combination of tact and firmness he was able to resist all attempts to lower the standard of survey, and, in the face of grudging support, to carry out a considerable portion of his original scheme. Maclear's arc has still to be extended to Port Nolloth, and this extension to be connected with Mr. Bosman's excellent triangulation in Bechuanaland; the eastern end of the latter triangulation has to be connected with the geodetic triangles near Kimberley, and Kimberley, through the Orange Free State, with the Natal triangulation. When these operations have been completed, let us hope in a not far distant future, they will yield an arc of 14 of longitude.

Dr. Gill's success thus far leads him to look forward and ask whether the progress made in geodetic survey in South Africa might not be regarded as the first step in a chain of triangulation which shall extend continuously to the mouth of the Nile. Further he would, by an additional chain of triangles along the coast of the Levant, and through the islands of Greece, connect the African and Greek triangulations, and so, with Struve's great arc of meridian, measure an arc of meridian $105^{\circ}$ in amplitude. Even though the completion of a work of such magnitude cannot be expected for many years to come, Dr. Gill has done good service by pointing out the mode of procedure that might be adopted, and the desirability of at once undertaking the definite survey of Egypt. Proposals for such a survey were made soon after the British occupation, but, for financial reasons, which would probably be still urged, they were not entertained. We trust, however, that the commencement of a work of such economic value to Egypt, and of such geodetic importance, will not be much longer delayed.

Dr. Gill was most fortunate in the officer selected to take charge of the field operations. Captain (now Lieut.Colonel) Morris, R.E., C.M.G., made, personally, nearly the whole of the astronomical observations, and of the measurements of the angles of the triangulation, as well as the greater part of the computations. He also arranged for the transport of the delicate instruments over much rough country, managed distant heliostat parties, looked after men, horses and cattle, and, with much tact, persuaded the farmers to allow beacons and observatories to be erected on their lands. When it is remembered that the 18 -inch theodolite with its stand weighed I042 lbs., and that it was packed in five boxes, of which that containing the body of the instrument weighed 400 lbs., the transport difficulties are apparent. The able manner in which Colonel Morris carried out his duties may be gathered from his Report, which fills a large portion of the Blue-book, and the fact that no breakdown occurred at any time throughout the work. As Dr. Gill well says: "Colonel Morris' services have been such as very few men have the combined physique and capacity to render."

The survey was carried out with great care and accuracy with the improved instruments of the present day, and it takes a high place amongst the geodetic surveys of the world. The standard of measure was the Cape ro-foot standard Bar A., the length of which, in terms of the international mètre, was determined at Breteuil by M. Benoit, then Chief Assistant of the International Bureau of Weights and Measures. The constants of two Tonnelot thermometers, for employment in the comparison of the base-apparatus with the standard, were also investigated at Breteuil under the direction of Dr. Brock. The base-measuring apparatus, made by Troughton and Simms, consisted of five 10-foot steel bars, "so mounted as to be conveniently handled and aligned, and provided with means for determining the instantaneous temperature of each bar." The steel bars were compared with the standard by means of an instrument, the Comparateur, designed by Dr. Gill, of which a full description, with plates, is given.

Three base-lines were measured, each by a different method. The Natal base was measured throughout its whole length, $10,800^{\circ} 45$ feet. The line was divided into three sections of about 3600 feet, and each section was measured backwards and forwards in successive horizontal 5o-foot lengths. The verification of the base showed a close agreement (a difference of 0002 feet in the one case, and of 0027 feet in the other) between the two outer sections as derived, respectively, by direct measurement, and by triangulation from the central section. As this appeared to show that accuracy could be obtained without the measurement of long base-lines, it was decided in the case of the Port Elizabeth base to measure only about 5600 feet, and afterwards to prolong it both wavs to a total length of $17,058.49$ feet. The measured base was divided into eight sections of 700 feet, each of which was measured forward in ascending, and backward in descending temperatures, and the measurements were, as far as possible, completed the same day. In the Kimberley base 6000 feet were measured, and the prolongation to $14,760^{\circ} 3$ feet was all in one direction. Here the measured base was divided into twelve sections, so as to ensure the completion of the forward and backward measurements in the same day. The probable errors in the lengths of the three bases are: Natal $\pm 0^{\circ} 140$ inches; Port Elizabeth $\pm 0^{\circ} 072$ inches; Kimberley $\pm 0 \circ 8 \mathrm{I}$ inches. The probable error of the Zwaartland base, measured by Maclear with the Colby compensating apparatus used for the measurement of the Lough Foyle base, is $\pm 2 \cdot 362$ inches.

For the triangulation two instruments were used: an r8-inch theodolite by Troughton and Simms, and a Io-inch theodolite by Repsold of Hamburg. The larger theodolite, though an admirable instrument, was inconvenient from its great weight and bulk; and, in spite of every care, the pivots, being made of comparatively soft material, became slightly deformed by wear. The Repsold theodolite was much more portable than the I8-inch, being less than a quarter its weight; it had hardened steel pivots which stood seven years' hard service, and it could be used both as a transit instrument and as a zenith telescope. It was consequently exclusively used, after its introduction, for astronomical observations, and the measurement of horizontal angles; and it seems to be an excellent instrument for geodetic work in a country where difficulties of transport may be expected. The probable error of an observed angle with the 18 -inch is $\pm 0^{\prime \prime} \cdot 49$, and with the ro-inch $\pm 0^{\prime \prime} \cdot 33$. These results, especially the latter, compare well with those of the best geodetic surveys of other countries. Those obtained with the Repsold are only inferior to the results of the survey of Saxony $\left( \pm \mathrm{O}^{\prime \prime} \cdot 23\right.$ ), and of the U.S. Coast Survey-San Francisco and Salt Lake series $\left( \pm \mathrm{O}^{\prime \prime} \cdot 25\right)$. The interesting table of probable errors of measurement of a single angle in the best surveys given by Dr. Gill, shows how far the Ordnance Survey (probable error $\left.\pm I^{\prime \prime} \cdot I 9\right)$ has been left behind by more recent surveys, and how desirable it is, from a scientific point of view and in the interests of geodesy, that the angles of the principal triangulation should be remeasured with the more perfect instruments of the present day.

The measured bases of the South African survey were connected by chains of triangles; and other stations, including those of Maclear's survey, were adjusted to the system of the geodetic circuit. A good account of the circuit solution is given by Colonel Morris in his Report. The observations of vertical angles were generally taken in the afternoon, when the effects of vertical refraction were most uniform, and the heights were adjusted on the same principle as the horizontal angles. The results were satisfactory. The difference between the levelled height of Zwaartkop Mountain NO. I 4 I9, VOL. 55] 
station, and the height, determined by computation, through a chain of triangles over 400 miles long, from Buffelsfontein station, the height of which was determined by levelling operations at Port Elizabeth, was only I 6 feet.

Most of the astronomical observations were made with the Repsold theodolite, but before its arrival the latitudes were determined by a Talcott zenith telescope, constructed by Troughton and Simms. As regards latitudes the preliminary results only are given, for since the observations were made the whole of the stars have been reobserved on the meridian with the Cape transit circle. The origin of all the longitudes is the centre of the transit circle, and all the results depend upon signals exchanged with the Cape Observatory. The longitude of Durban was determined as part of the work in the telegraphic connection of the longitudes of Aden and the Cape; and observations of longitude were made at other places, as circumstances admitted, by Colonel Morris, Mr. Maclear, and Mr. Pett. Astronomical observations of azimuth were made at several of the principal stations, and the observed azimuths were referred to lines of the principal triangulation.

The survey, on the whole, appears to give results slightly in favour of Airy's elements of the earth as compared with Clarke's, but, as Dr. Gill remarks, this conclusion must be adopted with great reserve. For final results we must await the completion of Dr. Gill's original scheme.

Colonel Morris' Report contains a statement of the formulæ and methods of computation, with the auxiliary tables employed, which will be of the greatest use to Government surveyors in the colony; and his whole Report will be of great assistance to any one who has to conduct similar operations in other parts of the world. The Report is illustrated with excellent lithographic plates of the theodolites, the base-measuring apparatus, Comparateur, triangulation, \&c., and the Government printers at the Cape have successfully carried out what must have been to them no easy task.

C. W. WILSON.

\section{IN THE AUSTRALIAN BUSH AND ON THE} COAST OF THE CORAL SEAS.

PROF. RICHARD SEMON, of Jena, the author of the above volume, will be well known to biological readers in connection with the valuable monographs that, under the title of "Zoologische Forschungsreisen in Australien und dem Malayischen Archipel," have been produced by himself, Prof. Ernst Haeckel, E. von Martens, and other accomplished collaborators as the outcome of his travels and collections in the aforesaid regions during the years $1891-92$.

The treatise under review is written in an essentially popular vein. It is a narrative of his voyage out to Australia; residence in and investigations conducted concerning the fauna of limited districts of that island continent ; and of his homeward route, with a detour embracing New Guinea and a considerable area of Malaya. The larger section, associated with the title of "The Australian Bush," deals only with portions of the easternmost of the six Australian colonies, that of Queensland. The main object of Prof. Semon's expedition was the investigation of the embryological phenomena of those archaic zoological types peculiar to the Australian region. The lung-fish, Ceratodus Forsteri, and the monotrematous mammals Platypus and Echidna, whose unique, egg-laying habits were for the first time incontestably demonstrated some years since $(1884)$ by our fellow1 "Im Australischen Busch und an den Küsten des Korallenmeeres-Reiseerlebnisse und Beobachtungen eines Naturforschers in Australien, NeuGuinea und den Molukken." Von Richard Semon. 8vo, pp. xiv +556 Mit 85 Abildungen und 4 Karten. (Leipsig: Wilhelm Engelmann, I896.) NO. 14 I9, VOL. 55$]$ countryman, Mr. W. H. Caldwell. With this specified end in view, M. Semon proceeded to South Queensland and camped out for several weeks on the banks of the rivers Burnet and its tributary the Boyne, at some little distance from the townships of Gayndah and Coonambula. All three of the zoological types named are indigenous to this watershed (Ceratodus existing nowhere else), and by making liberal use of the assistance of the semi-civilised natives an abundant supply of the materials desired were obtained. While a few of the more salient developmental phases of Ceratodus and Echidna are figured in this volume, their detailed histological delineation and description are relegated to the monographs previously cited.

As the result of the first week's work, and the offered reward of half-a-crown for each female Echidna, one alone of the several natives engaged brought in as many as six of these monotremes, and a large assortment of other animals, altogether making good his claim for eleven shillings, after deducting rations. The outcome of the prompt payment of the rewards earned was somewhat disastrous. During Prof. Semon's absence from the camp the succeeding day, the natives contrived to exchange their hard cash for "fire-water" at the nearest hostelryan undoubted breach of the regulations on the part of the vendor-and with the consequence that every man, woman and child, some thirty all told, were, on the learned Professor's return, dead drunk. A similar bacchanalian carouse, with threatened hostilities among themselves, is recorded as having followed the payment of the yet more liberal prize of 100 marks $(£ 5)$, that was awarded to the first of the band of aborigines to bring in the ova of Ceratodus. In the case of such substantial sums being won by natives of such essentially child-like irresponsibility, the proper course would undoubtedly have been to have lodged the money for disbursal for their benefit in the hands of some one of the neighbouring responsible settlers.

In his brief reference to the life-habits of the Echidna, Prof. Semon places on record an interesting demonstration of the conspicuous homing instincts, and also of the travelling capabilities of the species. An example brought into the camp from a distance of no less than 6 kilometres, escaped in the night from the sack in which it was confined. A native following up its track, found it the following morning reposing in close vicinity to the spot where it was originally captured. The data chronicled, though apparently not from direct observation, concerning the food habits of the Echidna, in M. Semon's book, are somewhat at variance with those personally determined. It is here stated that worms and insects of all descriptions (Kerbtieren aller Art), though more particularly ants, constitute its normal pabulum. Also that ants, in the ordinary sense of the term, are devoured after the fashion peculiar to the typical ant-eaters, Myrmecophagida. With the several examples kept by the writer for long intervals; and which becoming tame were permitted to seek their nourishment in their native "bush," it was found that these Echidnæ not only limited their attention to ants, but in this connection cared only for the white succulent larva and pupæe or, so-called, eggs. Ants in their ordinary adult form, as in a teeming ant-track, would be altogether ignored. At the same time while consuming the larvæ, to gain access to which they tear open the hillocks, or overturn stones with their powerful claws, a considerable number of adult ants may be adventitiously injested.

The quest for the ova of Ceratodus proved to be a more lengthened task. No less than eight months were occupied in obtaining an accurate knowledge of that animal's spawning season, and in registering the developmental features of the ova when obtained. The persevering search, coupled with the handsome reward offered to the natives previously recorded, resulted in the ultimate acquisition of an abundant supply of material, 